\title{
高 $\mathrm{Na}$ 透析の血圧，ヘマトクリット，血漿浸透圧 および血管作動性物質に及ぼす影響
}

\author{
八木祝子猪狩友行石井策史西山敬介 \\ 平田 恭 信* \\ 日本赤十字社医療センター内科 東京大学第 2 内科*
}

key words : 高 $\mathrm{Na}$ 透析, 血圧, ヘマトクリット, 血漿浸透圧, 心房性 $\mathrm{Na}$ 利尿ペプチド

〈要旨〉

高 $\mathrm{Na}$ 透析の血圧, ヘマトクリット $(\mathrm{Ht})$, 血墏浸透圧および血管作動性物質に及ぼす影響を標準透析の場合と比較 した. 高 $\mathrm{Na}$ 透析は標準透析液 ( $\mathrm{Na} 140 \mathrm{mEq} / \mathrm{l})$ に高 $\mathrm{NaCl}$ 液を注入して $\mathrm{Na}$ 濃度を $155 \mathrm{mEq} / l$ に上け゚て前半 2 時 間透析し，後半は標準透析液に戻す方法で行った。血圧は携帯型自動血圧計で 24 時間測定した.

透析前後の体重と除水量は両透析間で差異がなかったが, 透析中の血圧は高 $\mathrm{Na}$ 透析で有意に高く, 透析終了後は 有意ではないが高い傾向が 24 時間認められた。

高 $\mathrm{Na}$ 透析では標準透析に比べて血墏 $\mathrm{Na}$ 濃度が透析 2 時間後および終了時に有意に高く $(\mathrm{p}<0.01), 2$ 時間後 の血漿浸透圧も有意に高かった $(p<0.05)$. 一方, Ht は高 $\mathrm{Na}$ 透析で透析前および 2 時間後で有意に低值であった $(p<0.001)$.

血漿心房性 Na 利尿ペプチド濃度 (ANP) は両透析で透析により著明に減少した。血漿レニン活性 (PRA) は両透析 ともに透析中に有意な変化がみられなかったが, アルドステロン濃度 $(P A C)$ は高 $\mathrm{Na}$ 透析中に有意の減少がみられ た. 血漿ノルアドレナリン (NA) およびアドレナリン濃度 $(A)$ は両透析で透析 2 時間後に有意に減少したが, 終了 時にはほぼ透析前值に復した。両透析の間で透析前, 2 時間後および終了時の ANP, PRA, PAC, NA およびA 值に有 意の差異がみられなかった。

高 $\mathrm{Na}$ 透析では透析中の血漿 Na 濃度および血漿浸透圧がより高く維持されるために細胞内および組織間から血管 内へ水の移動が速やかに行われ, 循環血漿量の減少率が少ないことが血圧の安定に寄与すると考えられる.

\section{Effects of high sodium hemodialysis on blood pressure, hematocrit, plasma osmolality, and vasoactive substances}

Noriko Yagi, Tomoyuki Igari, Kazutika Ishii, Keisuke Nishiyama, Yasunobu Hirata* Department of Medicine, Japanese Red Cross Medical Center; Second Department of Internal Medicine, University of Tokyo*

The effects of high sodium hemodialysis (HD) on blood pressure, hematocrit, plasma osmolality and vasoactive substances were studied in 10 chronic HD patients and compared with those of standard HD.

High sodium HD was carried out for the first 2 hours with a high sodium dialysate ( $\mathrm{Na} 155 \mathrm{mEq} / \mathrm{l}$ ) consisting of a constant injection of high salt solution into the standard dialysate, and then standard dialysate ( $\mathrm{Na} 140 \mathrm{mEq} /$ l) was used for the last 2 to 3 hours.

Blood pressure was measured at one hour intervals for 24 hours using an ambulatory blood pressure monitor. Although there was no significant difference in pre- and post-dialysis body weight and removed fluid volume between high sodium HD and standard HD, significantly higher blood pressure was observed during high sodium $\mathrm{HD}$ and the hypertensive tendency persisted after HD.

八木 祝子 東京大学第 2 内科 ₹ 113 文京区本郷 7-3-1 (03-3815-5411)

〔受付: 平成 4 年 1 月 8 日, 受理: 平成 4 年 7 月 30 日〕 
As compared with the standard HD, the high sodium HD showed a significantly higher concentration of plasma sodium at 2 hour- and post-dialysis tests ( $p<0.01$ for both) and a significantly higher plasma osmolality at 2 hour-dialysis test $(p<0.05)$. The hematocrit, however, was significantly lower at pre- and 2 hour-dialysis tests $(p<0.001$ for both).

While atrial natriuretic peptide (ANP) significantly decreased during both forms of HD, plasma renin activity (PRA) did not change significantly with either HD. Plasma aldosterone concentration (PAC) significantly decreased with high sodium dialysate, but not with standard dialysate.

Plasma noradrenaline (NA) and adrenaline (A) were significantly decreased at 2 hour-dialysis test and increased to the pre-dialysis levels after HD. There was no significant difference between the high sodium HD and the standard HD in the plasma levels of ANP, PRA, PAC, NA, and A at the pre-, 2 hour- or post-dialysis tests.

These results suggest that intracellular and extracellular fluid moved into the vascular space more quickly and compensated for the reduction of circulatory plasma volume on high sodium HD.

\section{緒言}

近年，性能の優れた透析膜が開発されて透析時間が短 縮される傾向にあるが，これは一方では透析患者の水分 過唾, 電解質異常, 高血漿浸透圧などの体液異常を短時 間で是正することとなり，血圧低下や不均衡症候群を生 む原因となる ${ }^{1)}$.

この対策として透析液 $\mathrm{Na}$ 濃度を上げて透析する高 $\mathrm{Na}$ 透析や cell-wash dialysis が試みられる ${ }^{2 \sim 6)}$. 高 $\mathrm{Na}$ 透析は血漿浸透圧を維持することで細胞内液および細胞 間液から血管内腔への水の移動を促進して血圧低下や不 均衡症候群の出現を抑えるのに役立つが，口渴を強める ために水分貯留や血圧上昇をおこす危険がある。

著者らは非生理的高 $\mathrm{Na}$ 透析液を透析前半の 2 時間の み使用する方法で高 $\mathrm{Na}$ 透析を施行し, 血圧, $\mathrm{Ht}$, 血漿 浸透圧および血管作動性物質への影響を調べた.

\section{対象と方法}

1. 対象

症状の安定した外来透析患者 10 例（男 5 例，女 5 例） を対象とした。年齢は 40〜60 歳, 平均 51 歳で, 透析期 間は $1 \sim 9$ 年である. 基礎疾患は慢性系球体腎炎 6 例, 糖尿病性腎症, 多発性囊胞腎, 腎結石, コレステロール 塞栓症がそれぞれ 1 例である。

\section{2. 方法}

標準透析にはキンダリーAF-2P 液 $(\mathrm{Na}$ 濃度 140 $\mathrm{mEq} / l)$ を使用した。高 $\mathrm{Na}$ 透析はこれに高濃度 $\mathrm{NaCl}$ 液を持続注入して $\mathrm{Na}$ 濃度 $155 \mathrm{mEq} / l$ の透析液を作製 して前半の 2 時間を透析し, 後半は標準透析液で透析す る方法をとった．透析は週 3 回で 1 回の透析時間は 4 な いし 5 時間であり, 透析開始は午前 9 時からである.

標準透析と高 $\mathrm{Na}$ 透析でそれぞれ 4 週間透析したあ と, 透析直前, 透析 2 時間後抢よび透析終了時に採血し て Ht, 一般生化学, 血漿浸透圧, ANP, PRA, PAC, NA および $\mathrm{A} を$ 測定した。血圧および脈拍数は非シャント側
の上腕で携帯型自動血圧計（コーリン，ABPM-630）を 用いて 1 時間毎に測定した。 24 時間の血圧測定は上記の 血圧計を使用し，原則として採血日に行った。ANP, PRA およびPAC は RIA 法で, NA とAは HPLC 法 で測定した。

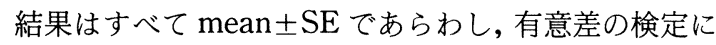
は Student's t test を用いて， p < 0.05 を有意とした。

\section{結果}

高 $\mathrm{Na}$ 透析では標準透析に比べて透析中の口渴が強い 傾向があったが，透析前の体重は標準透析 $59.1 \pm 2.1 \mathrm{~kg}$, 高 $\mathrm{Na}$ 透析 $59.5 \pm 2.3 \mathrm{~kg}$, 透析後の体重はそれぞれ 56.4 $\pm 2.1 \mathrm{~kg}, 56.7 \pm 2.2 \mathrm{~kg}$ および除水量はそれぞれ $2.72 \pm$ $0.37 \mathrm{~kg}, 2.75 \pm 0.19 \mathrm{~kg}$ で, 透析法の違いによる差はみられ なかった.

高 $\mathrm{Na}$ 透析の血圧は高 $\mathrm{Na}$ 透析液が使用される前半 2 時間には変化がみられないが, 標準透析液になる後半で は下降し, 終了時には収縮期血圧が有意に下降した $(\mathrm{p}<$ $0.05)$.

標準透析の血圧は平均としては漸次下降する傾向がみ られるが，バラツキが大きく有意差はみられなかった。 血圧值を透析間で比較すると高 $\mathrm{Na}$ 透析で透析前の拡張 期血圧と 2 時間後の収縮期血圧が標準透析に比べて有意 に高かった（ $\mathrm{p}<0.05 ） （$ 図 1$)$. 脈拍数は透析中に有意 な変化を示さず，透析間の比較でも有意差がみられな かった.

血漿 $\mathrm{Na}$ 濃度は高 $\mathrm{Na}$ 透析では透析前值の $140.8 \pm 1.5$ $(\mathrm{mEq} / l)$ から 2 時間後には $145.2 \pm 0.7$, 終了時には $141.0 \pm 0.5$ と変化し, 高 $\mathrm{Na}$ 透析液使用中に有意に上昇 $(\mathrm{p}<0.001)$ し，透析終了時には前值に復した。一方， 標準透析での変化は $140.4 \pm 1.2(\mathrm{mEq} / l)$ から $139.8 \pm$ $0.8,138.4 \pm 0.6$ と低下傾向を示したが有意ではなかっ た。これを透析間で比較すると透析前では差異がなく， 高 $\mathrm{Na}$ 透析液使用中の 2 時間後および標準透析液に戻し 

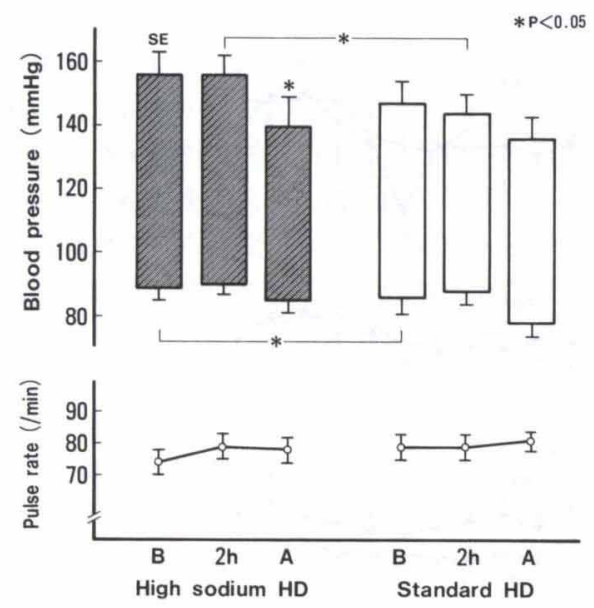

図 1 Blood pressure and pulse rate before, during 2 hour and after hemodialysis. $\mathrm{HD}$ : hemodialysis, $\mathrm{B}$ : before $\mathrm{HD}, 2 \mathrm{~h}$ : during 2 hour $\mathrm{HD}, \mathrm{A}$ : after HD.

た終了時において高 $\mathrm{Na}$ 透析で有意に高值であった $(\mathrm{p}<0.01)$ (図 2 ).

血漿浸透圧は高 $\mathrm{Na}$ 透析では $320 \pm 3.5(\mathrm{mOsm} / \mathrm{kg}$ ・ $\left.\mathrm{H}_{2} \mathrm{O}\right)$ から $311 \pm 2.1,297 \pm 1.7$ へと低下し, 標準透析で は $326 \pm 3.3\left(\mathrm{mOsm} / \mathrm{kg} \cdot \mathrm{H}_{2} \mathrm{O}\right)$ 加 $305 \pm 1.7,294 \pm 0.9$ へと低下した.これらの変化はいずれの場合も透析前值 に比べて有意であったが $(\mathrm{p}<0.001)$. 高 $\mathrm{Na}$ 透析と標 準透析間で比較すると透析開始 2 時間後の浸透圧が高 $\mathrm{Na}$ 透析で有意に高かった $(\mathrm{p}<0.05)$ (図 2$)$.

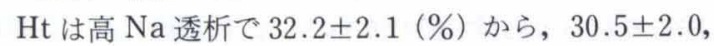
$36.4 \pm 2.2$, 標準透析では $33.6 \pm 1.9$ (\%) から， $33.5 \pm$ $2.0,38.5 \pm 2.7$ へと変化した. すなわち, $\mathrm{Ht}$ は高 $\mathrm{Na}$ 透 析では透析 2 時間後に有意に低下したが(平均 $-1.7 \%$ ), 標準透析では不変であり, 透析終了時には高 $\mathrm{Na}$ 透析, 標準透析ともに有意に上昇した(それぞれ $\mathrm{p}<0.05, \mathrm{p}<$ 0.01). 透析法による相違を検討すると, 透析前と透析 2 時間後の $\mathrm{Ht}$ が高 $\mathrm{Na}$ 透析で有意に低かったが, 終了時 には差異がみられなかった（図 3 ).

血漿アルブミン濃度の変化は $\mathrm{Ht}$ のそれに似たが, 高 $\mathrm{Na}$ 透析の 2 時間後の変化は有意でなかった. しかしな がら, 高 $\mathrm{Na}$ 透析と標準透析間で比較すると透析 2 時間 後の值は高 $\mathrm{Na}$ 透析で有意に低值であった $(\mathrm{p}<0.01)$ (図 3 ).

ANP, PRA, PAC, NA およびAの透析前, 透析 2 時 間後および終了時の值は表にまとめた.

ANP はいずれの透析法でも, 透析 2 時間後に有意に 低下し, 終了時にはさらに低下して前値のほほ５0\%のレ

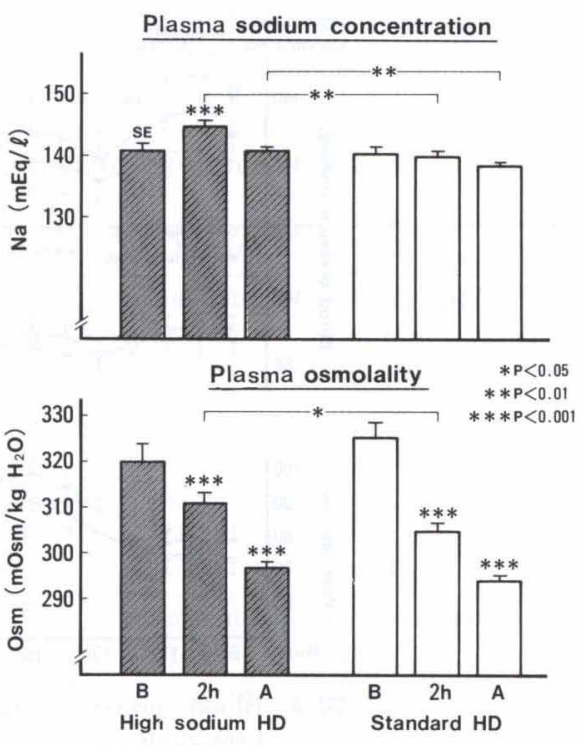

図 2 Plasma sodium concentration and plasma osmolality on high sodium and standard hemodialysis. HD : hemodialysis, B : before HD, $2 \mathrm{~h}$ : during 2 hour $\mathrm{HD}, \mathrm{A}$ : after HD.

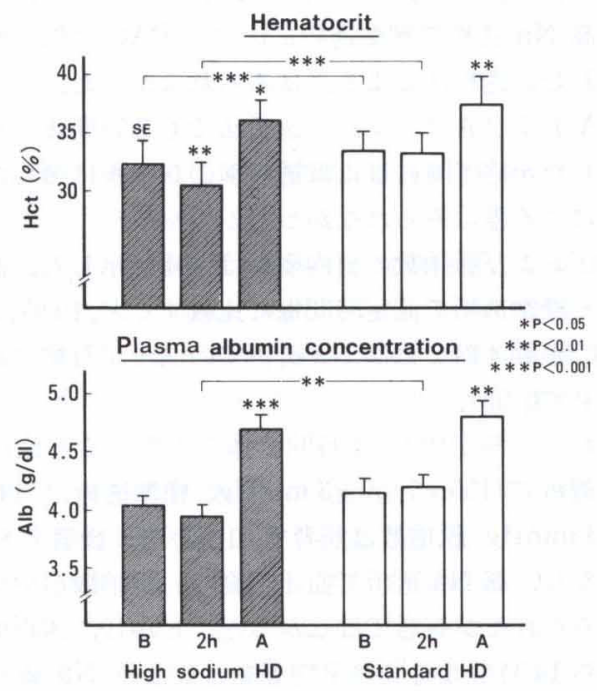

図 3 Hematocrit and plasma albumin concentration on high sodium and standard hemodialysis. HD : hemodialysis, B : before $\mathrm{HD}, 2 \mathrm{~h}$ : during 2 hour $\mathrm{HD}, \mathrm{A}$ : after HD.

ベルになった. 透析前, 透析開始 2 時間後および終了時 のANPには透析法による差がみられなかった（いずれ も $\mathrm{p}>0.1$ ).

PRA はいずれの透析法でも透析で有意な変化を示さ 

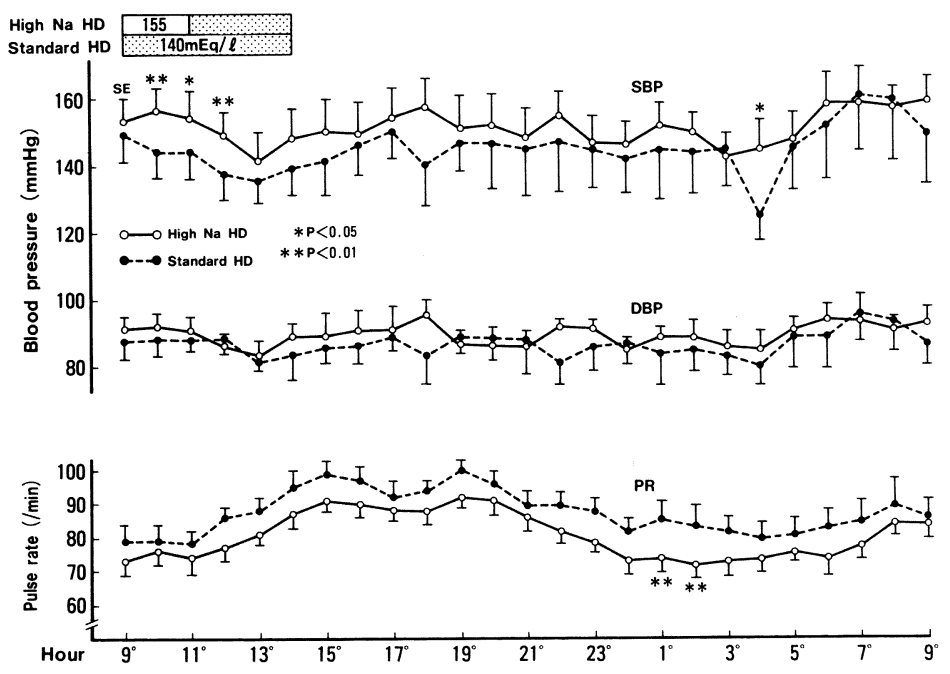

図 4 Blood pressure and pulse rate monitering during and after hemodialysis.

なかった。高 $\mathrm{Na}$ 透析で PRA が低い傾向がみられたが 有意ではなかった。

$\mathrm{PAC}$ は高 $\mathrm{Na}$ 透析で 2 時間後に有意に低下したが $(\mathrm{p}<0.05)$, 標準透析では有意な低下はみられなかった. また高 $\mathrm{Na}$ 透析で標準透析に比べて PAC は低い傾向が みられたが透析法による差はみられなかった。

NA およびA はいずれの透析法でも 2 時間後に有意に 低下したが終了時にはほぼ透析前のレベルに復した。透 析法による差はみられなかった。

血圧および脈拍数の日内変動は図 4 に示した。高 $\mathrm{Na}$ 透析と標準透析で測定時間毎に比較すると, 10 時, 11 時, 12 時, 翌朝 4 時では高 $\mathrm{Na}$ 透析での血圧が有意に高かっ た $(\mathrm{p}<0.05)$.

これらの測定值を 24 時間全体で平均すると血圧は高 $\mathrm{Na}$ 透析で $150 \pm 7 / 89 \pm 3 \mathrm{mmHg}$, 標準透析で $141 \pm 8 /$ $85 \pm 4 \mathrm{mmHg}$, 脈拍数は前者で $81 \pm 3$ /分, 後者で $87 \pm 4$ / 分となり, 高 $\mathrm{Na}$ 透析で血圧が高く, 脈拍数が少ない傾 向がみられたが有意ではなかった。しかし，透析中の 9 時から 14 時の 5 時間の平均值をとると高 $\mathrm{Na}$ 透析の収 縮期血圧は有意に高く $(\mathrm{p}<0.05)$ ，脈拍数は有意に少な かった $(\mathrm{p}<0.01)$.

\section{考察}

血液透析はダイアライザーを通して透析と限外濾過を 行い，腎不全患者の体液異常を短時間で是正するために 血圧低下や不均衡症候群がしばしばおこる．この原因と して循環血漿量の減少, 血墏浸透圧の低下, 酸塩基平衡 の変化, 血管作動性物質の変化, 自律神経機能不全, 心 機能抑制, 末梢血管拡張などが挙げられている7 が, 十分
には解明されていない。限外濾過により水分を除去する と循環血漿量が減少して血管内圧が低下する。一方，除 水により血漿は濃縮されて膠質浸透圧が高まる．血管内 圧低下と血漿膠質浸透圧上昇は細胞内および組織間の水 分の血管内への流入を促進し循環血漿量の減少を補充す る。一方，交感神経活動の元進による末梢血管の収縮が 同時におこり血管内圧の低下を防ぐ。

透析患者の血漿浸透圧は図 2 に示すように健常者に比 べてかなり高い值を示す。これは尿素をはじめとする窒 素代謝物の体内蓄積によるものである.これらが透析で 除去されると血漿浸透圧が低下し, 浸透圧の高い組織間 液へ血管内の水分が移動する。組織間液浸透圧の低下に より水分は相対的に浸透圧の高い細胞内へさらに移動し て細胞内溢水がおこる.かような機序による脳圧および 眼圧の方進は不均衡症候群の原因となる.

高 $\mathrm{Na}$ 透析液を使用すると血漿窒素代謝物が除去され ても血漿中の $\mathrm{Na}$ と $\mathrm{Cl}$ 濃度が上昇するために血漿浸透 圧の低下は少なく, 除水によって循環血獎量が減少して も，細胞内抢よび組織間の水分が速やかに血管内腔へ移 動する, すなわち plasma refilling rate が高いために循 環血漿量の減少が少なく血圧の低下が抢こりにくい.こ の際に血漿および組織間液の浸透圧が十分に高いと細胞 内溢水はおこらず，Na-free water が除去されて代謝面 でも改善がみられる4).

しかし, 透析液 $\mathrm{Na}$ 濃度の上昇は口渴を強めて水分貯 留と高血圧をひきおこす危険がある。そこで，著者らは 高 $\mathrm{Na}$ 透析液を前半 2 時間のみ使用し, 後半は標準透析 液に戻すという方法で高 $\mathrm{Na}$ 透析を施行した。その結果 
は高 $\mathrm{Na}$ 透析で標準透析に比べて透析中の口渴感が少し 強まる傾向はあったが, 透析前後の体重や除水量には全 く差異がみられなかった。

血圧は高 $\mathrm{Na}$ 透析で透析前および透析中の血圧が有意 に高いという結果を得たが, 透析後では高い傾向はある ものの有意差がみられなかった。この点から著者らの高 $\mathrm{Na}$ 透析は患者に負担をかけずに行いうる方法であると 考える。

除水は通常は一定速度で行われたので両透析ともに前 半 2 時間の除水量は平均 $1.3 \mathrm{~kg}$ と推測される. 標準透析 ではこの間の血漿 $\mathrm{Na}$ 濃度は不変で浸透圧は平均 21 $\mathrm{mOsm} / \mathrm{kg} ・ \mathrm{H}_{2} \mathrm{O}$ 低下したが, 高 $\mathrm{Na}$ 透析では血漿 $\mathrm{Na}$ 濃度が平均 $4.4 \mathrm{mEq} / l$ 上昇し浸透圧の低下は $9 \mathrm{mOsm} /$ $\mathrm{kg} \cdot \mathrm{H}_{2} \mathrm{O}$ と少なかった。

透析液と患者血清の $\mathrm{Na}$ 濃度が等しい場合には除水量 のほぼすべては細胞外液量（組織間液十循環血漿量）の 減少によるものであるが, 透析液 $\mathrm{Na}$ 濃度が患者血清の それより高くなると細胞内液の除去される比率が増加す ると報告されている ${ }^{8,9)}$. Van-Stone $ら^{8)}$ は透析液 $\mathrm{Na}$ 濃 度が $140 \mathrm{mEq} / l$ の場合には除水される細胞内液と細胞 外液の量は $7.1 \%$ 対 $92.9 \%$ で，血漿量の減少は $34 \%$ あ るのに対して透析液 $\mathrm{Na}$ 濃度が $160 \mathrm{mEq} / l$ に上昇する とその比は $42 \%$ 対 $58 \%$ となり血漿量の減少は $9.2 \%$ と 少なくなると報告した. Funck-Brentano ${ }^{9)}$ は透析液 $\mathrm{Na}$ 濃度が $150 \mathrm{mEq} / l$ では $\mathrm{Na}$-free water clearance は僅 かだが, $160 \mathrm{mEq} / l$ を超えると急速に増加すると報告し た.

本研究の標準透析液の $\mathrm{Na}$ 濃度は $140 \mathrm{mEq} / l$ で血漿 のそれとほぼ等しいことから除水量の大部分は細胞外液 量の減少によるものと考えられる。一方, 高 $\mathrm{Na}$ 透析で は前半 2 時間の透析液 $\mathrm{Na}$ 濃度は $155 \mathrm{mEq} / l$ であるの で,この間の除水量 $1.3 \mathrm{~kg}$ に関しては細胞内液の減少に よる面も多く，血嶈量の減少は比較的少ないと推測され る.

透析患者の $\mathrm{Ht}$ 值は血漿量の変化をよく反映すると報 告されている ${ }^{10)}$. 高 $\mathrm{Na}$ 透析で透析 2 時間後の $\mathrm{Ht}$ 值が 僅かだが有意に減少した。これは回路およびダイアライ ザー内にある生理的食塩水による血液希釈 ( ${ }^{*}$ 注) と細胞 内液減少による赤血球容積の縮小によるもので, 循環血 漿量は除水による影響をほとんど受けていないと考えら れる ${ }^{11)}$.すなわち, 血漿浸透圧が高く維持されているため に細胞内液および組織間液の水分による plasma refilling が速やかなためと推察される.

高 $\mathrm{Na}$ 透析と標準透析の両者で透析後半に Ht 值と血 漿アルブミン濃度の上昇がみられるのは十分な除水が行 われたことに加え血漿浸透圧が低下して, plasma refil-
表 Atrial natriuretic peptide, plasma renin activity, aldosterone concentration, noradrenaline and adrenaline concentration. * $\mathrm{p}<0.05, * * \mathrm{p}<0.01$ as compared with before HD. NS : not significant as compared between high sodium HD and standard HD.

\begin{tabular}{|c|c|c|c|}
\hline & Before & $2 \mathrm{~h}$ & After \\
\hline & \multicolumn{3}{|c|}{ Atrial natriuretic peptide $(\mathrm{pg} / \mathrm{m} l)$} \\
\hline High $\mathrm{Na} \mathrm{HD}$ & $230 \pm 50$ & $185 \pm 39^{*}$ & $116 \pm 26^{* *}$ \\
\hline \multirow[t]{2}{*}{ Standard HD } & $195 \pm 41$ & $162 \pm 38^{*}$ & $109 \pm 22^{* *}$ \\
\hline & NS & NS & NS \\
\hline & \multicolumn{3}{|c|}{ Plasma renin activity $(\mathrm{ng} / \mathrm{m} l / \mathrm{h})$} \\
\hline High $\mathrm{Na} \mathrm{HD}$ & $3.7 \pm 1.8$ & $3.3 \pm 1.1$ & $3.4 \pm 1.2$ \\
\hline \multirow[t]{3}{*}{ Standard HD } & $4.6 \pm 2.2$ & $5.3 \pm 2.3$ & $5.3 \pm 2.2$ \\
\hline & NS & NS & NS \\
\hline & \multicolumn{3}{|c|}{ Plasma aldosterone concentration $(\mathrm{pg} / \mathrm{m} l)$} \\
\hline High $\mathrm{Na} \mathrm{HD}$ & $324 \pm 101$ & $134 \pm 31^{*}$ & $235 \pm 77$ \\
\hline \multirow[t]{3}{*}{ Standard HD } & $443 \pm 168$ & $388 \pm 180$ & $708 \pm 371$ \\
\hline & NS & NS & NS \\
\hline & \multicolumn{3}{|c|}{ Plasma noradrenaline concentration $(\mathrm{ng} / \mathrm{m} l)$} \\
\hline High $\mathrm{Na} \mathrm{HD}$ & $0.41 \pm 0.08$ & $0.27 \pm 0.04^{*}$ & $0.30 \pm 0.03$ \\
\hline \multirow[t]{3}{*}{ Standard HD } & $0.40 \pm 0.05$ & $0.23 \pm 0.02^{* *}$ & $0.33 \pm 0.03$ \\
\hline & NS & NS & NS \\
\hline & \multicolumn{3}{|c|}{ Plasma adrenaline concentration $(\mathrm{ng} / \mathrm{m} l)$} \\
\hline High $\mathrm{Na} \mathrm{HD}$ & $0.033 \pm 0.005$ & $0.016 \pm 0.002^{*}$ & $0.025 \pm 0.006$ \\
\hline Standard HD & $0.054 \pm 0.014$ & $0.019 \pm 0.003^{*}$ & $0.052 \pm 0.021$ \\
\hline & NS & NS & NS \\
\hline
\end{tabular}

ling rate が落ちるために循環血漿量の減少が十分に補 充されなくなるためと思われる。

透析直前の透析患者は overhydration のために心房 圧が高く, ANP 分泌が元進している. 除水による心房圧 低下は ANP 分泌を減少させ, ANP の血中半減期は 2 分以内と短いためにこれは直ちに血漿 ANP 濃度に反映 される ${ }^{12 \sim 14)}$.

本研究でも透析法を問わず透析前の ANP が異常に高 く，透析後は低下することが確認された．この際に循環 血漿量の減少が顕在化しない透析 2 時間後にANP の有 意の減少がみられ, 心房圧の低下が示唆される. 血漿 ANP 濃度は, 循環血液量を反映して変化し透析患者の 体液量の推定に有用であると報告されている ${ }^{15)}$. しかし ながら, 今回の我々の検討では, 高 $\mathrm{Na}$ 透析で透析前お よび透析 2 時間後の $\mathrm{Ht}$ 值が標準透析に比べて低く, 循 環血液量の増加が示唆されたが, 対応する時期の ANP には有意差がみられなかった。

PRA は透析で増加するとの報告が多いが不変との報 告もある ${ }^{15,16)}$, 透析中の PRA と血清 $\mathrm{Na}$ 濃度との間に は負の相関関係がみられるという ${ }^{16)}$. 本研究では透析に より PRA に有意の変化がみられなかった. 高 $\mathrm{Na}$ 透析 
では PRA は標準透析に比べて低值であったが有意差が なかった.

アルドステロン分泌は ACTH, レニン・アンジオテン シン系および血清 K濃度によって調節されることが知ら れている ${ }^{17)}$ が,さらに, 副腎皮質細胞内の $\mathrm{Na}$ 濃度によっ てもアルドステロン分泌が調節されている可能性のある ことが指摘されている ${ }^{18,19)}$. PAC は透析中にレニン・ア ンジオテンシン系の元進が怙きると昇するが，一方， 透析により血清 K濃度が低下すると分泌は抑制されるの で低下する ${ }^{16,20,21)}$. 透析中の $\mathrm{PAC}$ は血清 $\mathrm{K}$ 濃度と正の相 関を示し, 血清 $\mathrm{Na}$ 濃度とは負の相関をすると報告され ている ${ }^{18)}$. PAC は標準透析では有意の変化を示さない が，高 $\mathrm{Na}$ 透析では透析 2 時間で低下した。この $\mathrm{PAC}$ の低下は, PRA と血漿K濃度に差異がないことから血漿 の $\mathrm{Na}$ 濃度の上昇が副腎皮質の細胞内 $\mathrm{Na}$ 濃度を上昇さ せてアルドステロン分泌を抑制した可能性が示唆され る.

透析により血漿カテコラミン濃度は増加, 不変あるい は減少すると報告されている ずれの透析法でも NA および A は透析 2 時間後に有意 に減少したが終了時にはほほ透析前のレベルに復した。 これは透析前半では透析による血漿カテコラミンの除去 が大きく影響するが, 後半になると血圧低下や循環血漿 量減少の影響でカテコラミン分泌が急速に高まるためと 思われる。

携帯型自動血圧計による血圧および脈拍数の日内変動 から高 $\mathrm{Na}$ 透析の影響は透析後もみられることが示され た. 血圧変動は高 $\mathrm{Na}$ 透析でも標準透析でも健常者で検 討された成績と同様に ${ }^{23)}$ 日中が高く夜間就寝時に低い周 期性を示したが, 高 $\mathrm{Na}$ 透析を行った場合の血圧がより 安定している傾向が認められた。

\section{結論}

高 $\mathrm{Na}$ 透析では標準透析に比べて透析中の血漿 $\mathrm{Na}$ 濃 度と高 $\mathrm{Na}$ 透析施行中の血漿浸透圧が高く, 透析中の血 圧も, より高く維持され, 透析後もこの傾向が持続した. また, 高 $\mathrm{Na}$ 透析では透析前の $\mathrm{Ht}$, 高 $\mathrm{Na}$ 透析を 2 時間 行った時点での $\mathrm{Ht}$ および血漿アルブミン濃度が標準透 析に比べて低下していたが, 透析中の ANP, PRA, NA およびAの変化に有意の差はみられなかった.PAC は高 $\mathrm{Na}$ 透析で低下した.

高 $\mathrm{Na}$ 透析では透析中に血漿 $\mathrm{Na}$ 濃度や血漿浸透圧が 高く維持されるために細胞内および組織間から血管内へ 水の移動が速やかに行われ，循環血漿量の減少率が少な いことが低血圧と不均衡症候群の出現を少なくしている と考えられる。
* 注 著者らは回路およびダイアライザー内にある生理的食 塩水による血液希釈の影響をみるために, 10 例で透析前 と透析開始 10 分後の $\mathrm{Ht}$ を調べた. Ht は透析前の 28.8 \pm 1.5 (SE)\%より 10 分後に $27.2 \pm 1.4 \%$ へと変化し, 平 均 $1.6 \pm 0.2 \%$ の減少がみられた $(\mathrm{p}<0.001)$ (未発表).

\section{文献}

1) 前田憲志：不均衡症候群. 日本臨牀 43 (特別号, 維 持透析）：133-145，1985

2）斉藤 豊：希釈濃度による高 $\mathrm{Na}$ 透析の検討。腎と 透析 $12: 421-425,1982$

3）小木幸人, 西村昌美, 河内弥生, 今田聡雄, 堀内 篤: 無症状透析のための透析液浸透圧の検討一高浸透圧 透析一. 透析会誌 $13: 555-559,1980$

4）前田憲志：高 $\mathrm{Na}$ 透析. 透析会誌 $15 ： 103-113,1982$

5）佐谷 誠：透析困難症と重炭酸，高ナトリウム透析 一有効浸透圧 (tonicity) の観点より一.内科 MOOK $31: 221-230,1986$

6) Maeda K, Kawaguchi S, Kobayashi S, Niwa T, Kobayashi K, Saito A, Iyoda S, Ohta K : Cellwash dialysis. Ttans Am Soc Artif Intern Organs $26: 213-218,1980$

7）今村陽一，久保明義，松原 涉，熊谷晴光，原田実 篤, 松本 勲, 竹中正治, 白石恒雄: 透析中の血圧 維持機構に関する臨牀的研究一体液性因子と心機能 の影響一。目腎誌 $28: 439-445,1986$

8) Van Stone JC, Bauer J, Carey J : The effect of dialysate sodium concentration on body fluid distribution during hemodialysis. Trans Am Soc Artif Intern Organs $26: 383-386,1980$

9) Funck-Brentano JL: Sodium-free water clearance in hemodialysis. Artificial Organs $5: 51-53$, 1981

10) Tuchman J, Blumberg A : Serial measurements of total blood volume in patients on maintenance hemodialysis. Klin Wochenschr 54 : 735-738, 1976

11）小野慶治：標準抢よび高 $\mathrm{Na}$ 透析液による透析前後 の心電図所見. 腎と透析 $12: 329-333,1982$

12）丸茂文昭, 上山三代子：腎不全と ANP. 最新医学 $43: 105-109,1988$

13）安藤亮一, 石田雄二, 前川 清, 松田 治, 三宅祥 三, 石山直樹, 高橋弘一, 川越正孝: 透析患者にお ける血中ヒト心房性 $\mathrm{Na}$ 利尿ペプチド。透析会誌 $21: 607-612,1988$

14) Elias AN, Vaziri ND, Pandian MR, Kaupke J : 
Plasma concentrations of atrial natriuretic peptide, arginine vasopressin and hormones of the renin angiotensin system in patients with endstage renal disease. Int J Artif Organs 12 : 153158, 1989

15）赤井洋一, 草野英二, 古谷裕章, 大野修一, 江幡 理, 手塚俊文, 安藤康宏, 鈴木宗弥, 田部井薰, 浅野 泰: 透析患者の ANP は体液貯留の指標となりうるか? 透析会誌 $24 ： 1143-1148,1991$

16) Rouh WR, Hund E, Sohl G, Rascher W, Mehlis O, Scharer $\mathrm{K}$ : Vasoactive hormones in children with chronic renal failure. Kidney Int 24 (Suppl 15) : S-27-33, 1983

17) Quinn SJ, Williams GH : Regulation of aldosterone secretion. Ann Rev Physiol 50 : 409-426, 1988

18) Lobo MV, Marusic ET, Aguilera G: Further studies on the relationship between potassium and sodium levels and adrenocortical activity. Endocrinology 1061-1068, 1978
19) Matsuoka $H$, Ishii $M$, Yamakado $M$, Uehara $Y$ : Effect of natrium ionophore on aldosterone production in the rat adrenal gland. Endocrinology 115 : 2039-2044, 1984

20) Blumberg A, Weidmann P, Shaw S, Gnadinger $\mathrm{M}$ : Effect of various therapeutic approaches on plasma potassium and major regulating factors in terminal renal failure. Am J Med 85 : 507-512, 1988

21) Kramer BK, Ulshofer TM, Muller GA, Ress KM, Risler $\mathrm{T}$ : Regulation of plasma aldosterone during hemodialysis. Int J Artif Organs $13: 32-38$, 1990

22) Ratge D, Augustin R, Wisser H : Catecholamines, renin, aldosterone and arterial pressure in patients on chronic hemodialysis treatment. Int $\mathrm{J}$ Artif Organs 6 : 255-260, 1983

23）栃久保修：血圧の測定法と臨床評価. p 67-99, メ ディカルトリビューン, 東京, 1988 